\title{
Budaya Organisasi Dalam Membentuk Karakter Generasi Khaira Ummah Di Pesantren
}

\author{
Izah Ulya Qadam \\ Institut Agama Islam Negeri (IAIN) Kudus, Kudus, Indonesia \\ izahchoiron.kopri@iainkudus.ac.id
}

\begin{abstract}
Abstrak
Budaya organisasi adalah seperangkat nilai, kepercayaan dan pemahaman penting yang sama-sama dimiliki oleh para anggotanya. Nilai-nilai atau ide-ide dan kepercayaan bahwa yang sama-sama dianut oleh para anggota itu seperti terwujud dalam alat-alat simbolis seperti mitos, upacara, cerita, legenda, dan bahasa khusus. Budaya organisasi adalah hal yang paling penting dalam memperbaiki efektifitas organisasi dan manajerial. Kinerja organisasi tidak cukup dan tidak akan dapat dipahami jika tidak melihat budaya dalam organisasi tersebut secara komprehensif. Pengembangan organisasi dan pengembangan sumber daya organisasi yang profesional akan membawa keberhasilan organisasi dimasa depan, yaitu yang memahami dan menggunakan strategi organisasi dan memahami budaya organisasi. Generasi khaira ummah adalah generasi yang benar-benar memiliki intelektualitas dan berakhlaqul karimah serta mengamalkan intelektualitasnya sesuai dengan ajaran al-Qur'an dan al-Hadits yang Rahmatan lil alamin. Dalam konteks keindonesiaan adalah mereka yang konsisten mengamalkan dan berpegang teguh pada ajaran Ahlussunnah Wal Jama'ah dan menjunjung tinggi Negara Kesatuan Republik Indonesia. Makalah ini akan membahas tentang budaya organisasi dalam membentuk generasi khaira ummah di pondok pesantren, budaya organisasi sebagai perangkat nilai yang dimiliki oleh para anggotanya baik santri, guru, tata administrasi untuk menjadi pribadi yang tangguh sebagaimana karakter khaira ummah. Pada santri disiapkan dengan berbagai macam kegiatan yang mendukung pembentukan karakter umat yang mampu berbicara disemua bidang baik ilmu agama atau ilmu pengetahuan dan tantangan di era revolusi industri 4.0 serta pada akhirnya mampu mewujudkan perdamaian dunia. Mengingat kondisi teknologi yang selalu berubah, diperlukan kemampuan adaptasi yang tinggi agar santri tidak ketinggalan zaman dan mampu bersaing dan nilainilainya sendiri.
\end{abstract}

Kata Kunci: Budaya Organisasi,Generasi Khaira Ummah 


\begin{abstract}
Organizational Culture in Forming Character Khaira Ummah Generation in Islamic Boarding Schools. Organizational culture is a set of important values, beliefs and understandings that are shared by its members. The values or ideas and beliefs that are shared by the members are manifested in symbolic tools such as myths, ceremonies, stories, legends and special languages. Organizational culture is the most important thing in improving organizational and managerial effectiveness. Organizational performance is not enough and will not be understood if you do not see the culture in the organization comprehensively. Organizational development and professional organizational resource development will bring organizational success in the future, that is, who understands and uses organizational strategy and understands organizational culture. Khaira ummah generation is the generation that truly has intellect and morality and practices the intellect in accordance with the teachings of the Qur'an and al-Hadith that Rahmatan lil alamin. In the context of Indonesianness, they are those who consistently practice and hold fast to the teachings of Ahlussunnah Wal Jama'ah and uphold the Unitary State of the Republic of Indonesia. This paper will discuss organizational culture in shaping the generation of khaira ummah in Islamic boarding schools, organizational culture as a set of values owned by its members both santri, teachers, and administrative procedures to become strong individuals as the character of khaira ummah. The students are prepared with a variety of activities that support the formation of the character of the people who are able to speak in all fields of religion or science and challenges in the era of the industrial revolution 4.0 and ultimately able to realize world peace. Given the ever-changing technological conditions, high adaptability is needed so that students are not out of date and are able to compete and their own values.
\end{abstract}

Keywords: Organizational Culture, Khaira Ummah Generation

\title{
A. Pendahuluan
}

Salah satu agenda utama bangsa Indonesia adalah reformasi penyelenggaraan Negara yang diarahkan untuk meningkatkan integritas, profesionalitas, dan tanggung jawab dalam penyelenggaraan Negara, serta memberdayakan masyarakat untuk melakukan kontrol sosial secara konstruktif 
dan efektif. Budaya organisasi adalah hal yang paling penting dalam memperbaiki efektifitas organisasi dan manajerial.

Wilkins dan Ouchi (1983) menyebutkan bahwa kinerja organisasi tidak cukup dan tidak akan dapat dipahami jika tidak melihat budaya dalam organisasi tersebut secara komprehensif. Pengembangan organisasi dan pengembangan sumber daya organisasi yang profesional akan membawa keberhasilan organisasi di masa depan, yaitu yang memahami dan menggunakan strategi organisasi dan memahami budaya organisasi (Wilkins \& Ouchi, 1983).

Meneliti budaya organisasi dapat dilakukan untuk melihat pembentukan, pertahanan, kekuatan dan kelemahan sebuah organisasi. Sebaliknya, untuk melakukan reformasi lembaga pendidikan juga dapat dilakukan dengan mengembangkan budaya organisasi yang akan berpengaruh terhadap individu, tata nilai, sistem aturan, struktur, dan mekanisme dalam organisasi lembaga pendidikan. Budaya organisasi yang mampu beradaptasi dengan tuntutan perubahan dan pengisi peluang yang ada akan mampu bertahan hidup (survive) dan berkembang ke arah yang lebih baik. Budaya organisasi merupakan bagian yang tidak terpisahkan dari lingkungan internal organisasi karena keragaman budaya yang ada dalam suatu organisasi sama banyak dengan jumlah individu yang ada didalam organisasi. Setiap karyawan mempunyai ciri dan karakteristik budaya masing-masing sehingga tidak tertutup kemungkinan adanya karyawan yang menyukai dari yang tidak, sehingga diperlukan suatu penyatuan persepsi dari seluruh karyawan atas pernyataan budaya organisasi, hal demikian merupakan uraian deskriptif dari budaya organisasi.

Generasi khaira ummah adalah generasi yang benar-benar memiliki intelektualitas dan berakhlaqul karimah serta mengamalkan intelektualitasnya sesuai dengan ajaran al-Qur'an dan al-Hadits yang Rahmatan lil alamin. Dalam konteks keindonesiaan adalah mereka yang konsisten mengamalkan dan berpegang teguh pada ajaran Ahlussunnah Wal Jama'ah dan menjunjung tinggi Negara Kesatuan Republik Indonesia.

Pondok pesantren adalah bagian dari pendidikan di Indonesia. Ini adalah blueprint dari generasi Islam masa depan dan masyarakat Islam dimasa depan. Banyak dari kalangan masyarakat yang mengharapkan pondok pesantren mampu dalam mencetak generasi-generasi khoira ummah yaitu generasi yang memiliki keagungan akhlak, kedalaman spiritual, keluasan ilmu, dan kematangan profesional sebagai langkah mengimplementasikan ajaran Islam sebagai rahmat bagi semesta alam (Rahmatan lil alamin). 
Artikel ini membahas tentang budaya organisasi dalam membentuk generasi khaira ummah di pondok pesantren, budaya organisasi sebagai perangkat nilai yang dimiliki oleh para anggotanya baik santri, guru, tata administrasi untuk menjadi pribadi yang tangguh sebagaimana karakter khaira ummah. Pada santri disiapkan dengan berbagai macam kegiatan yang mendukung pembentukan karakter umat yang mampu berbicara disemua bidang baik ilmu agama atau ilmu pengetahuan dan tantangan di era revolusi industri 4.0 serta pada akhirnya mampu mewujudkan perdamaian dunia. Mengingat kondisi teknologi yang selalu berubah, diperlukan kemampuan adaptasi yang tinggi agar santri tidak ketinggalan zaman dan mampu bersaing dan nilai-nilainya sendiri.

\section{B. Pembahasan}

\section{Konsep Budaya Organisasi}

Budaya organisasi merupakan kesepakatan bersama tentang nilai-nilai bersama dalam kehidupan organisasi dan mengikat semua orang dalam organisasi yang bersangkutan. F.E. Kast dan Rozenzweig (1974: 193) mendefinisikan budaya organisasi sebagai seperangkat nilai, kepercayaan dan pemahaman penting yang sama-sama dimiliki oleh para anggotanya. Ia menyatakan nilai-nilai atau ide-ide dan kepercayaan bahwa yang sama-sama dianut oleh para anggota itu seperti terwujud dalam alat-alat simbolis seperti mitos, upacara, cerita, legenda, dan bahasa khusus.

Edgar H. Schein (2010: 44) mendefinisikan bahwa A pattern of basic assumption-invented, discovered, or development by a given as it learns to cope with its problems of external adaptation and internal integration-that has worked well enough to be considered valid and therefore, to be taugh to new members as the correct way to perceives think and fell in relation to those problems (suatu pola dari asumsi dasar yang diciptakan, ditemukan atau dikembangkan oleh kelompok tertentu saat belajar menghadapi masalah adaptasi eksternal dan integrasi internal yang telah berjalan cukup baik untuk dianggap valid dan oleh karena itu untuk diajarkan kepada anggota baru sebagai cara yang benar untuk persepsi, berpikir, dan berperasaan sehubungan dengan masalah yang dihadapainya.

Selanjutnya berkaitan dengan "budaya organisasi (corporate culture)", Edgar H. Schein (2010) mengungkapkan bahwa budaya organisasi mempunyai beberapa maksud, yaitu: 
a. Observed behavioral regularities atau suatu keteraturan perilaku yang tampak. Yaitu suatu keteraturan perilkau yang biasanya terjadi pada saat orang mengadakan interaksi, misalnya bahasa-bahasa yang digunakan, kebiasaankebiasaan yang dilakukan.

b. The Norms, yaitu norma-norma yang berlaku dalam kelompok kerja atau organisasi

c. The Dominant Value espoused, yaitu suatu nilai-nilai dominan yang dianut oleh organisasi

d. The philosophy, yaitu falsafah yang diterapkan dan dianut atau dilaksanakan oleh organisasi yang bisa mengarahkan kebijakan-kebijakan organisasi dalam mencapai tujuannya.

e. The Rule, yaitu aturan-aturan main yang ada didalam organisasi dalam menghadapai hal-hal tertentu.

f. The Felling or Climate, yaitu iklim atau keadaan (sesuatu) dalam organisasi yang terasa dan dapat terlihat dari lay out fisik maupun cara-cara atau suasana anggota organisasi dalam berinteraksi dengan pelanggan/orang luar.

Oleh karena itu, budaya organisasi akan menentukan apa yang boleh dan tidak boleh dilakukan oleh para anggota organisasi; menentukan batas-batas normatif perilaku anggota organisasi; menentukan sifat dan bentuk-bentuk pengendalian dan pengawasan organisasi; menentukan gaya manajerial yang dapat diterima oleh para anggota organisasi; menentukan cara-cara kerja yang tepat, dan sebagainya (Suryono, 2001). Budaya organisasi adalah salah satu aspek yang menentukan keberhasilan suatu organisasi. Salah satu konsekuensi dari budaya organisasi yang kuat adalah meningkatnya perilaku yang konsisten dari tiap individu dalam organisasi (Sørensen \& Sorensen, 2002). Budaya organisasi berfungsi memberikan inspirasi dan memfasilitasi interaksi yang intense antara individu dan tim yang dibutuhkan untuk membangun kompetensi organisasi.

Pada umumnya budaya dibangun atau diciptakan oleh pendiri atau lapisan pimpinan atas yang mendirikan atau merintis perusahaan. Falsafah atau strategi yang ditetapkan oleh mereka lalu menjadi petunjuk dan pedoman bawahan mereka dalam melaksanakan tugas. Bila implementasi strategi ini ternyata berhasil dan dapat bertahan bertahun-tahun, maka filosofi atau visi yang diyakini tersebut akan berkembang menjadi budaya organisasi. Jika budaya organisasi tersebut dibakukan maka dalam implementasinya harus berfungsi sebagai alat ukur dari setiap kegiatan organisasi. 


\section{Proses Pembentukan Budaya Organisasi}

Secaraa teoritis proses bagaimana suatu budaya organisasi terbentuk, telah dijelaskan oleh Edgar H. Schein (2010) dalam bukunya Organization Culture and Leadership. Menurut beliau terbentuknya suatu budaya organisasi dapat diantara dari tiga teori:

\section{a. Teori Sociodynamic}

Teori ini menitik beratkan pengamatan secara detail mengenai kelompok pelatihan, kelompok terapi, dan kelompok kerja yang mempunyai proses interpersonal dan emosional guna membantu menjelaskan apa yang dimaksud dengan share terhadap pandangan yang sama dari suatu masalah dan mengembangkan share tersebut.

b. Teori Kepemimpinan

Teori ini menekankan hubungan antara pemimpin dengan kelompok dan efek personalitas dan gaya kepemimpinan terhadap formasi kelompok yang sangat relevan dengan pengertian bagaimana bentuk terbentuk.

c. Teori Pembelajaran

Teori memberikan bagaimana kelompok mempelajari kognitif, perasaan dan penilain. Secara structural, ada dua tipe pembelajaran : Situasi penyelesaian masalah secara positif dan Situasi menghindari kegelisahan. Proses pembelajaran dimaksudkan untuk pewarisan budaya organisasi kepada anggota baru dan organisasi.

Menurut Kotter dan Heskett (2008: 140), gagasan proses pembentukan budaya organisasi bisa berasal dari mana saja; dari perorangan atau kelompok, dari tingkat bawah atau puncak organisasi. Akan tetapi dalam perusahaan, gagasan ini sering dihubungkan dengan pendiri atau pemimpin awal yang mengartikulasikannya sebagai visi, strategi bisnis, filosofi, atau ketiga-tiganya. Edgar H. Schein juga menyatakan bahwa budaya organisasi diciptakan oleh pemimpin dan salah satu fungsi pemimpinan yang sangat menentukan adalah kreasi, manajemen dan jika perlu bisa merusak budaya.

Kotter dan Heskett (2008: 140) menyatakan bahwa budaya organisasi yang diciptakan oleh puncak tersebut kemudian diimplementasikan menjadi visi/filosofi atau strategi bisnis. Kemudian visi dan strategi tersebut diimplementasikan oleh anggota organisasi sehingga menjadi perilaku organisasi. 
Kepada anggota organisasi yang baru, bisa diajarkan gaya kelompk secara eksplisit.

Para manajer atau anggota senior kelompok organisasi mengkomunikasikan nilai-nilai pokok mereka terus-menerusdalam percakapan sehari-hari atau melalui ritual dan percakapan khusus. Proses komunikasi ini mendorong anggota baru untuk mengambil alih nilai-nilai pokok budaya organisasi tersebut untuk selanjutnya diterapkan dalam perilaku. Adopsi terhadap nilai-nilai pokok budaya organisasi tersebut dapat membawa organisasi/ perusahaan/lembaga memeliki budaya kuat dan berkinerja baik.

Proses terbentuknya budaya organisasi/ perusahaan menurut Kotter dan Heskett dapat dilihat pada gambar dibawah ini :

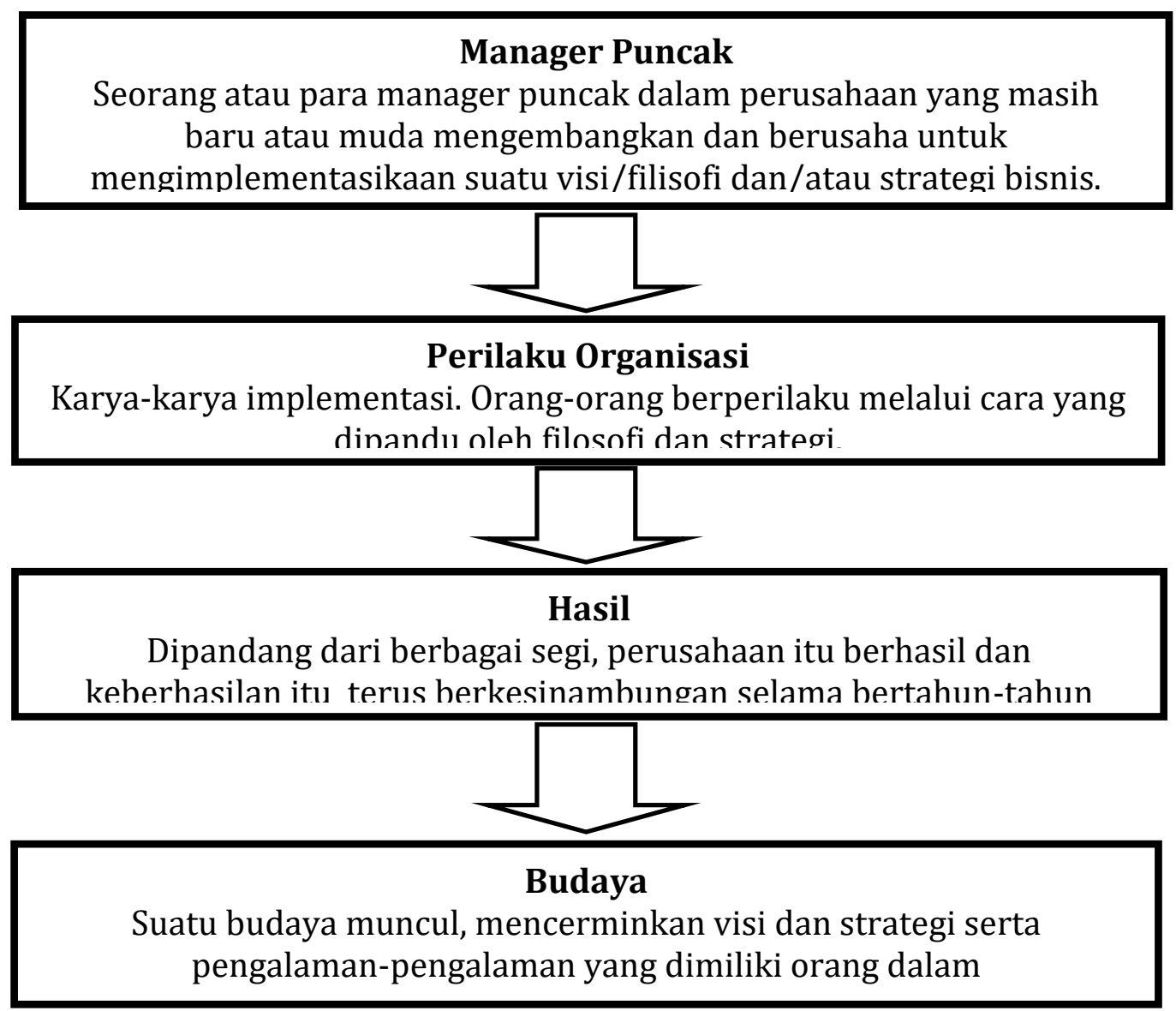

\section{Gambar 1}

Proses Terbentuknya Budaya Organisasi menurut Kotter dan Heskett (Sumber : Kotter dan Heskett, Corporate Culture and Performance, 1997) 


\section{Pembentukan Karakter}

Berbagai literatur ditemukan bahwa kebiasaan yang dilakukan secara berulang-ulang yang didahului oleh kesadaran dan pemahaman akan menjadi karakter seseorang. Dan gen hanya menjadi salah satu penentu. Sejauh mana gen menentukan karakter sesorang? Jika karakter merupakan seratus persen turunan dari orang tua, tentu saja karakter tidak bisa dibentuk. Namun jika gen hanyalah menjadi salah satu faktor dalam pembentukan karakter, kita akan menyakini bahwa karakter bisa dinentuk. Dan orang tualah yang mempunyai andil besar dalam membentuk karakter anaknya. Orang tua disini adalah yang mempunyai hubungan genetis yaitu orang tua kandung, atau orang tua dalam arti yang lebih luas orang-orang dewasa yang berada disekeliling anak dan memberikan peran yang berarti dalam kehidupan anak.

Dalam Islam, faktor genetis ini juga diakui keberadaannya. Salah satu contohnya adalah pengakuan Islam tentang alasan memilih calon istri atas dasar faktor keturunan. Rasul pernah bersabda yang intinya menyebutkan bahwa kebanyakan orang menikahi seorang wanita karena faktor rupa, harta, keturunan, dan agama. Meskipun Islam mengatakan bahwa yang terbaik adalah menikahi wanita karena pertimbangan agamanya namun tetap saja bahwa Islam mengakui adanya kecenderungan bahwa orang menikah karena ketiga faktor selain agama itu. Salah satunya adalah keturunan. Boleh jadi orang yang menikahi wanita karena pertimbangan keturunan disebabkan oleh adanya keinginan memperoleh kedudukan dan kehormatan sebagaimana orang tua si perempuan. Atau bisa juga karena ingin memiliki keturunan yang mewarisi sifat-sifat khas orang tua istrinya (Munir, 2010: 6).

Dasar pembentukan karakter itu adalah nilai baik dan buruk. Nilai baik disimbolkan dengan nilai Malaikat dan nilai buruk disimbolkan dengan nilai Setan. Karakter. Karakter manusia merupakan hasil tarik-menarik antara nilai baik dalam bentuk energi positif dan nilai buruk dalam bentuk energi negative. Energi positif itu berupa nilai-nilai etis religius yang bersumber dari keyakinan kepada Tuhan, 
sedangkan energi negative itu berupa nilai-nilai yang amoral yang bersumber dari taghut (Setan). Nilai-nilai etis moral itu berfungsi sebagai sarana pemurnian, pesucian dan pembangkitan nilai-nilai kemanusiaan yang sejati (hati nurani) (Munir, 2010: 6). Menurut Tobroni (2012) Energy positif itu berupa :

a. Kekuatan spiritual. Kekuatan spiritual itu berupa iman, Islam, ihsan dan taqwa yang berfungsi membimbing dan memberikan kekuatan kepada manusia untuk menggapai keagungan dan kemuliaan (ahsani taqwim).

b. Kekuatan potensi manusia positif, berupa aqlus salim (akal yang sehat), qolbun salim (hati yang sehat), qolbun munib (hati yang kembali, bersih, suci dari dosa) dan nafsul mutmainnah (jiwa yang tenang), yang kesemuanya itu merupakan modal insani atau sumber daya manusia yang memiliki kekuatan luar biasa.

c. Sikap dan perilaku etis. Sikap dan perilaku etis ini merupakan implementasi dari kekuatan spiritual dan kekuatan kepribadian manusia yang kemudian melahirkan konsep-konsep normative tentang nilai-nilai budaya etis. Sikap dan perilaku etis itu meliputi : istiqomah (integritas), ikhlas, jihad, dan amal sholeh.

Energi positif tersebut dalam perspektif individu akan melahirkan orang yang berkarakter, yaitu orang yang bertaqwa, memiliki integritas (nafs almutmainah) dan beramal saleh. Aktualisasi orang yang berkualitas ini dalam hidup dan bekerja akan melahirkan akhlak budi pekerti yang luhur karena memiliki personality (integritas, komitmen dan dedikasi), capacity (kecakapan) dan competency yang bagus pula (profesional). (Tobroni, 2012)

Kebalikan dari energi positif diatas adalah energi negative. Energi negative itu disimbolkan dengan kekuatan materialistik dan nilai-nilai thaghut (nilai-nilai desktruktif). Kalau nilai-nilai etis berfungsi sebagai sarana pemurnian, pensucian dan kebangkitan nilai-nilai kemanusiaan yang sejati (hati nurani), nilai-nilai material (thaghut) justru berfungsi sebaliknya yaitu pembusukan, dan 
penggelapan nilai-nilai kemanusian (Tobroni, 2012). Hampir sama dengan energi positif, energi terdiri dari : (Tobroni, 2012)

a. Kekuatan thaghut. Kekuatan thaghut itu berupa kufr (kekafiran), munafiq (kemunafikan), fasiq (kefasikan) dan syirik (kesyirikan) yang kesemuanya itu merupakan kekuatan yang menjauhkan manusia dari makhluk etis dan kemanusiaannya yang hakiki (ahsan taqwim) menjadi makhluk yang serba material (asfala saafilin).

b. Kekuatan kemanusiaan negatif, yaitu pikiran jahiliyah (pikiran sesat), qalbun maridl (hati yang sakit, tidak merasa), qalbun mayyit (hati yang mati, tidak punya nurani) dan nafsu 'l-lawwamah (jiwa yang tercela) yang kesemuanya itu akan menjadi manusia menghamba pada ilah-ilah selain Allah berupa harta, seks, dan kekuasaan (thaghut).

c. Sikap dan perilaku tidak etis. Sikap dan perilaku tidak etis ini merupakan implementasi dari kekuatan thaghut dan kekuatan kemanusiaan negatif yang kemudian melahirkan konsep-konsep normatif tentang nilai-nilai budaya tidak etis (budaya busuk). Sikap dan peilaku tidak etis itu meliputi : takabur (congkak) hub al-dunya (materialistik), dhalim (aniaya) dan amal sayyiat (destruktif).

Energi negatif tersebut dalam perspektif individu akan melahirkan orang yang berkarakter buruk, yaitu orang yang pucuk keburukannya meliputi syirk, nafs lawwamah dan 'amal al sayyiat (destruktif). Aktualisasi orang yang bermental thaghut ini dalam hidup dan bekerja akan melahirkan perilaku tercela, yaitu orang yang memiliki personality tidak bagus (hipokrit, penghianat dan pengecut) dan orang yang tidak mampu mendayagunakan kompetensi yang dimiliki (Tobroni, 2012).

Said Agil Al-Munawar (2003: 27) menjelaskan bahwa pembentukan kepribadian manusia melalui pendidikan budi pekerti juga tidak bisa terlepas dari faktor lingkungan, baik keluarga maupun masyarakat. Dalam kaitan ini, maka nilainilai akhlak mulia hendaknya ditanamkan sejak dini melalui pembudayaan dan 
pembiasaan. Kebiasaan itu kemudian dikembangkan dan diaplikasikan dalam pergaulan hidup kemasyarakatan. Disini diperlukan kepeloporan dan para pemuka agama serta lembaga-lembaga keagamaan yang dapat mengambil peran terdepan dalam membina akhlak mulia dikalangan umat. Pandangan para ilmuan dari Barat menyoroti masalah pendidikan dikenal adanya tiga teori :

1) Teori Nativisme

Teori ini mengemukakan bahwa manusia yang dilahirkan telah memiliki bakat-bakat dan pembawaan baik karena berasal dari keturunan orang tuanya, nenek moyangnya maupun karena ditakdirkan demikian, yang penganutnya antara lain: Scopenhauer yang mengatakan bahwa manusia itu tidak mengubah-ubah, akhlak manusia tetap seumur hidup (Musthafa, 2007: 39).

Penganut teori ini mengatakan bahwa lingkungan sekitar manusia tidak akan memberi pengaruh apa-apa dalam perkembangan manusia. Jika manusia membawa potensi jahat maka dalam perkembangannya ia akan menjadi jahat dan begitu juga sebaliknya, jika manusia sejak lahir membawa potensi baik, maka perkembangan hidup selanjutnya akan menjadi baik pula (Fatah, 2008: 189). Pandangan faham nativisme nampaknya terlalu mutlak menggantungkan kepada pembawaan diri manusia sejak lahir dan tidak menerima masukan apapun diluar diri manusia. Dalam perspektif pendidikan, teori ini memang bertolak belakang dari kenyataannya, bahwa kegiatan pendidikan umumnya telah berhasil membentuk, mengarahkan, dan menumbuh kembangkan bakat yang dibawa oleh manusia sampai menuju kearah yang diharapkan (kedewasaan), baik melalui proses pendidikan formal maupun non-formal (Fatah Yasin, 1995: 198).

2) Teori Empirisme

Teori empirisme (teori lingkungan) yang mengemukakan bahwa anak yang lahir itu laksana kertas yang putih bersih atau semacam tabularasa (meja lilin), dimana kertas dapat ditulis dengan tinta macam warna apa saja. Inilah teori John Lock yang hampir sama mengikuti teori Rasulullah tersebut, yaitu 
bahwa anak lahir dalam keadaan suci bersih, tergantung kedua orang tuanya akan mencetaknya akan menjadi apa anaknya itu (Hidayatullah, 2010: 100).

Dalam perspektif pendidikan teori ini menganggap bahwa pendidik sanngat memegang peranan yang sangat penting terhadap peserta didik, sebab pendidik akan menyediakan lingkungan semaksimal mungkin dengan yang dikendaki oleh peserta didik. Lingkungan pendidikan ini kemudian disajikan dan dikondisikan oleh pendidik kepada peserta didik sebagai pengalamanpengalaman dalam kehidupannya dan selanjutnya melalui pengalamanpengalaman tersebut akan membentuk pengetahuan, sikap dan tingkah laku peserta didik sesuai dengan tujuan pendidikan yang diharapkan (Fatah, 2008: 60 ).

3) Teori Konvergensi

Teori yang tiga adalah konvergensi atau persesuaian diantara dua teori (Hidayatullah, 2010: 100). Teori ini dipelopori oleh William Stern dari jerman dengan pandangan yang lebih akomodatif. Hasil sintesa tersebut mengatakan bahwa manusia lahir di dunia ini telah membawa bakat dan sekaligus bakat itu tidak akan berfungsi jika tidak dikembangkan oleh lingkungan sekelilingnya. Jadi pembawaan dan lingkungan adalah dua hal yang tidak dapat dipisahkan. Lingkungan mendukung, tetapi bila bakat tidak ada maka pribadi manusia sulit untuk bisa berkembang dan sebaliknya, bila bakat itu ada tetapi lingkungan tidak mendukung juga sulit untuk berkembang (Fatah, 2008: 60).

Teori ini mengakui bahwa manusia sejak lahir di dunia ini sudah membawa bakat baik dan buruk. Oleh karena itu, jika manusia hidup dalam lingkungan yang baik, maka bakat baiknya itu akan berkembang dan begitu pula sebaliknya, jika manusia hidup dalam lingkungan yang jelek maka bakat jelek yang dibawa sejak lahir tersebut akan mudah untuk tumbuh dan berkembang. Untuk itu, pandangan dunia pendidikan menganggap bahwa manusia akan berkembang kearah mana yang dituju sangat bergantung pada lingkungan pendidikan yang diterimanya (Fatah, 2008: 60). 
Ajaran Islam yang datangnya lebih dahulu dari teori-teori tersebut sebenarnya tidak terpengaruh, sebab ajaran Islam itu berdiri terlepas daripada teori bikinan manusia. Disamping orang tua berkewajiban mendidik anaknya menjadi anak yang baik, juga berkewajiban si anak untuk menuntut ilmu yang bermanfaat baik bagi hidupnya di dunia maupun bagi kehidupannya di akhirat kelak sehingga ia akan bahagia hidup di dunia dan di akhirat (Hidayatullah, 2010: 101).

Dalam pandang Islam, ada kemungkinan besar hampir memiliki kesamaan. Hanya saja yang membedakan bahwa dalam Islam manusia sejak lahir telah membawa fitrah, yang tercermin dalam beragama Islam. Hadits riwayat Bukhori Muslim yang artinya: "Setiap anak terlahir dalam dalam keadaan fitrah, maka kedua orang tualah yang akan menentukan apakah ia akan menjadi pengikut Yahudi, Nasrani atau Majusi." (H.R. Bukhori dan Muslim).

Fitrah akan berkembang tergantung dari bagaimana lingkungan itu mempengaruhi. Lingkungan itu dapat mempengaruhi perkembangan manusia baik jasmani dan rohani. Lingkungan manusia yang paling aawal dan utama dalam membentuk dan mempengaruhi perkembangan manusia sejak lahir adalah kelurga. Anak manusia akan tumbuh dan berkembang menjadi manusia yang memiliki sifat dan karakter seperti Yahudi, Nasrani, dan Majusi yang mana sangat bergantung terhadap didikan dalam keluarga terutama yang diberikan oleh kedua orang tua (Fatah, 2008: 60).

Konsep fitrah dalam al-Qur'an juga bertentangan dengan teori yang menggangap, manusia itu sesungguhnya suci bersih. Pendukung aliran behaviorisme dalam psikologi memandang bahwa manusia itu ketika dilahirkan tidak mempunyai kecenderungan baik maupun jahat. Teori seperti ini yang kemudian disebut dengan "Teori Tabula Rasa”, lingkungan yang memainkan peran Dallam membentuk kepribadiannya. Menurut Skinner, "lingkungan menentukan kehidupan manusia ketika manusia ini melibatkan dirinya dengan lingkungan sekitar", maka manusia bukan warisan yang lebih dari refleksi-refleksi. Agama 
sebagaimana aspek-aspek lain dari tingkah laku manusia dapat mewujudkan kedalam terma-terma mengenai faktor-faktor lingkungan sekitar. Kenyataan membuktikan, bahwa anak seorang muslim biasanya menjadi muslim, sedangkan dari keturunan Kristen biasanya beragama Kristen. Bukti ini dicatat oleh Skinner sebagai contoh untuk menjelaskan teorinya (Rahardjo, 1974: 62).

Perubahan karakter manusia dalam pandangan Islam dipengaruhi oleh faktor pembentukan internal dan eksternal. Faktor pembentukan internal adalah faktor yang ada pada diri manusia itu sendiri sedangkan faktor eksternal adalah faktor yang berasal dari luar diri manusia tersebut. Kedua fitroh tersebut telah terangkai dalam kandungan surat al-Ashr : 1-3 yang artinya: "Demi masa. Sesungguhnya manusia itu benar-benar dalam kerugian. Kecuali orang-orang yang beriman dan mengerjakan amal saleh dan nasehat menasehati supaya mentaati kebenaran dan nasehat menasehati supaya menetapi kesabaran."(Q.S. al-Ashr : 1-3)

Faktor internal pembentuk karakter adalah iman dan amal sholih sedangkan faktor eksternal adalah nasihat dalam kebenaran dan nasihat dalam kesabaran. Juwairiyah (2010: 2) menjelaskan bahwa pada dasarnya semenjak lahir manusia sudah dianugrahi fitrah atau potensi untuk menjadi baik dan jahat, akan tetapi anak yang baru lahir berada dalam keadaan suci tanpa noda dan dosa. Oleh karena itu, apabila di kemudian hari dalam perkembangannya anak menjadi besar dan dewasa dengan sifat-sifat yang buruk, maka hal itu merupakan akibat dari pendidikan keluarga, lingkungan dan sahabat-sahabat sepermainannya yang notabene mendukung untuk tumbuh dan berkembangannya sifat-sifat buruk tersebut.

Menjadi sebuah tanggung jawab kedua orang tua dan semua orang dewasa untuk memberikan pendidikan dan bimbingan yang baik kepada putra-putrinya, agar kecenderungan taqwa dalam diri anak menjadi tumbuh dan berkembang dan bukan sebaliknya. Karena pada dasarnya setiap anak dibekali fitrah yang sama atau setara, seorang yang didalam hatinya ada iman akan dapat merasakan kondisi kejiwaan yang selalu selaras dengan fitrah, sebab kecenderungan bawaan yang 
berupa kecenderungan untuk beragama tauhid dan mengabdi kepada yang diyakini sebagai Maha Esa, telah dimilikinya. Akan tetapi, orang-orang kafir mereka terasingkan dari fitrahnya karena kecenderungan bawaan yang dikembangkannya hanyalah untuk selalu mengabdi kepada segala sesuatu selain Allah, maka potensi-potensi yang positif/potensi taqwanya menjadi terkesampingkan dan potensi-potensi negatif (fujurnya) yang menjadi berkembang (Juwairiyah, 2010: 2).

\section{Generasi Khaira Ummah}

Didalam al-Qur'an surat Ali Imran ayat 110, Allah SWT memberikan pangkat kepada umat Nabi Muhammad sebagai khaira ummah, yaitu umat yang terbaik. Allah SWT mengatakan "kuntum" bukan "antum". Redaksi "kana" merupakan fiil madli yang memiliki faidah "li al-dawam", artinya objek bicara ayat diatas dengan melihat redaksinya yang bersifat umum dapat dipahami bahwa objeknya adalah umat Nabi Muhammad SAW sepanjang zaman dan tidak hanya tertentu pada para sahabat yang hidup pada masa Rasulullah saat al-Qur'an diturunkan sebagaimana diriwayatkan bahwa Malik bin al-Shaif dan Wahb bin Yahudza yang keduanya keturunan Yahudi berkata kepada Ibn Mas'ud, Salim Maula Abi Hudzaifah, Mu'adz bin Jabal dan Ubay bin Ka'ab:

"Agama kami lebih baik dari agama yang kalian dakwahkan, bangsa kami lebih unggul dibanding kalian". Tidak lama kemudian turunlah ayat ini sebagai bantahan terhadap mereka. Asbabul nuzul dari turunnya ayat tersebut. Umat yang terbaik, setelah diutusnya Nabi Muhammad SAW sebagai Rasul, bukanlah Yahudi atau Nasrani tetapi umat Islam. Redaksi "khaira" merupakan af'al tafdhi yang menjadi mudhaf bagi isim nakirah ummah yang menerima sifat "ukhrijat linnas", artinya umat Islam memang secara lahiriyah dianugerahkan oleh Allah SWT memiliki potensi sebagai umat terbaik yang memberikan manfaat bagi keseluruhan umat manusia dengan syarat "ta'muruna bil ma'ruf, watanhauna 'anil munkar, wa tu'minuna billah". Tiga redaksi terakhir merupakan hal fi mahalli al- 
nashbi yang menjadi karakteristik untuk bisa disebut sebagai khaira ummah penggunaan jumlah fi'liyyah dengan fi'il mudhari' menjadi qarinah bahwa karakter tersebut menjadi prasyarat mutlak yang harus ada dalam setiap pribadi khaira ummah dan tidak boleh hilang selamanya. Dengan kata lain, pangkat atau gelar khaira ummah akan disandang oleh umat Nabi Muhammad SAW sepanjang mereka memiliki kekuatan dan keunggulan sehingga dapat menebarkan kebaikan, mencegah segala bentuk kemungkaran serta memiliki keimanan yang berkualitas.

Dalam satu hadits riwayat Imam Ahmad, al-Nas'i, dan al-Hakim yang artinya; "Sebaik-baik manusia adalah yang paling memiliki intelektualitas keilmuan dan paling memiliki ketakwaan kepada Allah, menyeluruh mengerjakan yang ma'ruf, mencegah dari perbuatan yang munkar, dan menyambung tali silaturrahmi. Hadits tersebut memberikan petunjuk adanya konektifitas antara ilmu dan amal, bahwasanya untuk menjadi generasi khaira ummah yang mengajak kepada kebaikan dan mencegah kemunkaran harus dibekali dengan kemampuan intelektualitas sehingga dalam beramal tidak keliru dan salah jalan.

Generasi khaira ummah adalah generasi yang benar-benar memiliki intelektualitas dan berakhlaqul karimah serta mengamalkan intelektualitasnya sesuai dengan ajaran al-Qur'an dan al-Hadits yang rahmatan lil alamin. Dalam konteks keindonesiaan adalah mereka yang konsisten mengamalkan dan berpegang teguh pada ajaran Ahlussunnah wal jama'ah dan menjunjung tinggi Negara Kesatuan Republik Indonesia.

\section{Budaya Organisasi Pondok Pesantren}

Budaya organisasi dalam lembaga pendidikan dikembangkan dengan nilainilai yang relevan dengan semangat visi lembaga tersebut, terutama keperpihakan terhadap proses belajar sebagai misi utama. Oleh karena itu nilai-nilai organisasi harus diarahkan pada pelayanan belajar yang optimal bagi siswa sehingga siswa dapat mengembangkan potensinya secara optimal. Unsur dalam budaya organisasi di lembaga pendidikan sebagai berikut: 


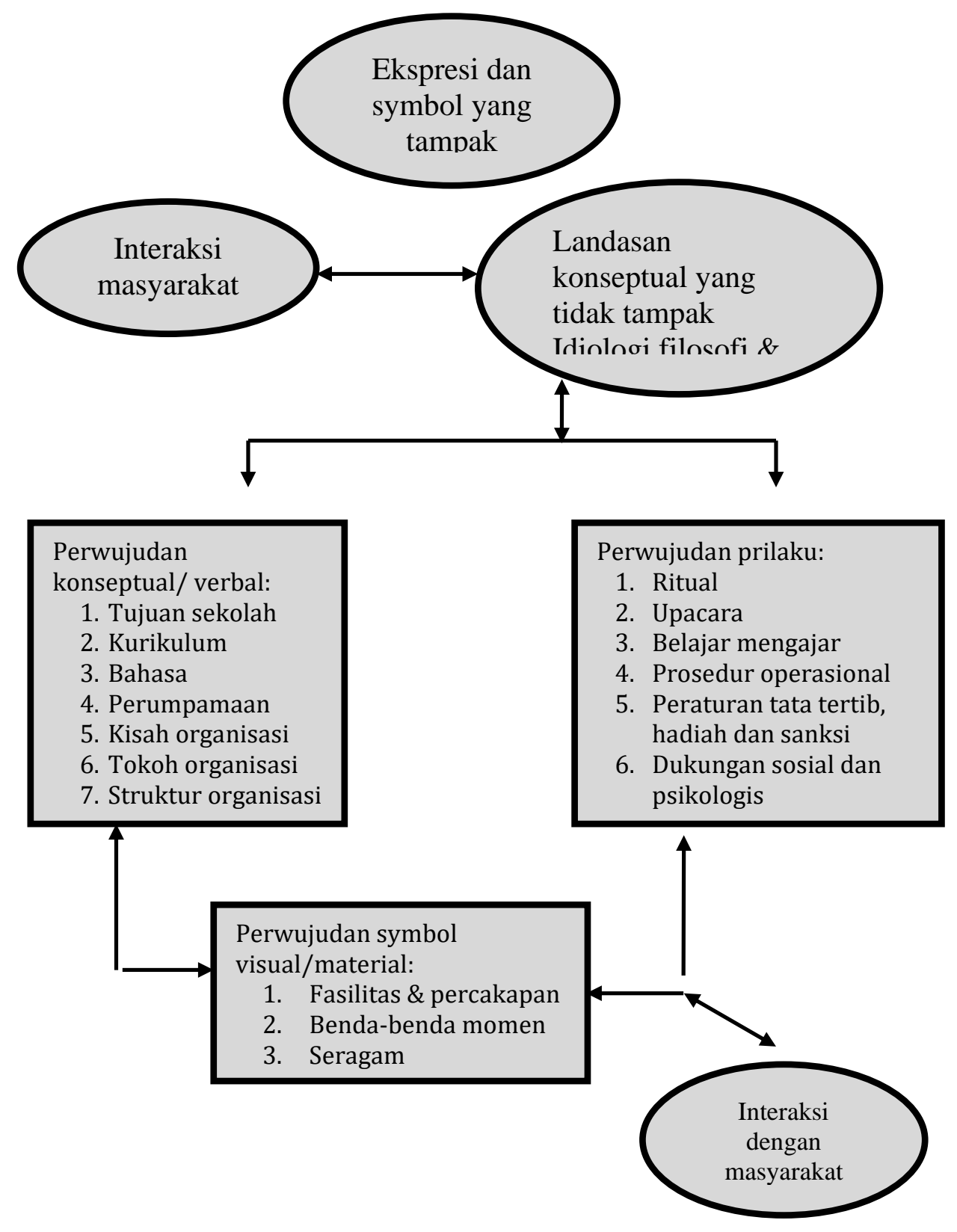

Gambar 2

Unsur Dalam Budaya Organisasi Di Lembaga Pendidikan

Pondok pesantren merupakan lembaga dan wahana pendidikan agama sekaligus sebagai komunitas santri yang "ngaji” ilmu agama Islam. Pondok pesantren sebagai lembaga tidak hanya identik dengan makna keislaman, tetapi juga mengandung makna keaslian (indigenous) Indonesia (Majid, 1997, p. 3), sebab 
keberadaannya mulai dikenal di bumi Nusantara para periode abad ke 13-17 M dan jawa pada abad ke 15-16 M (Mastuhu, 1994: 6).

Pondok pesantren pertama kali didirikan oleh Syekh Maulana Malik Ibrahim atau Syekh Maulana Maghribi (Wahjoetomo, 1997: 70). Atau Sunan Gresik yang dikenal sebagai spiritual father walisongo. Menurut Ronald Alan Lukens Bull, Syekh Maulana Malik Ibrahim mendirikan pondok pesantren di Jawa pada tahun 1399 M untuk menyebarkan Islam di Jawa (Lukens, 1997: 60). Namun dapat dihitung bahwa sedikitnya pondok pesantren telah ada sejak 300-400 tahun lampau. Usianya yang panjang ini kiranya sudah cukup alasan untuk menyatakan bahwa pondok pesantren telah memiliki budaya bangsa atau budaya pondok pesantren dalam bidang pendidikan dan telah ikut serta mencerdaskan kehidupan bangsa (Mastuhu, 1994: 7).

Secara faktual perkembangan pondok pesantren di Indonesia bisa dibedakan menjadi tiga bentuk, yaitu; 1) Salaf atau tradisional, 2) Khalaf atau modern, dan 3) Komprehensif atau kombinasi. Pertama, pesantren ini masih mempertahankan bentuk aslinya sebagaimana berlangsung sejak awal kemunculannya dengan semata-mata mengajarkan kitab-kitab (kuning) yang ditulis oleh ulama' klasik dengan menggunakan bahasa Arab. Model pengajarannya bisa berbentuk sorogan maupun bandongan dan jenjang pendidikan tidak berdasarkan tingkatan waktu melainkan dengan selesai atau khatamnya suatu kitab tertentu kemudian santri dapat naik kejenjang berikutnya dengan mempelajari kitab yang tingkat kesulitannya lebih tinggi dan seterusnya. Pendekatan ini sejalan dengan prinsip pendekatan modern yang dikenal dengan sistem belajar tuntas. Dengan cara ini santri dapat lebih intensif mempelajari suatu cabang ilmu. Kedua, pesantren khalaf, pondok pesantren ini menyelenggarakan kegiatan pendidikan dengan pendekatan modern melalui kegiatan formal, baik madrasah (MI, MTs, MA), maupun sekolah (SD, SMP, SMA, SMK) atau nama lainnya tetapi dengan pendekatan klasikan (jenjang kelas) dengan satuan program didasarkan pada satuan waktu. Pengajaran kitab-kitab Islam klasik tidak 
diselenggaran. Sekalipun bahasa Arab diajarkan, namun penguasaannya tidak diarahkan untuk memahami bahasa Arab yang terdapat dalam kitab-kitab klasik. Penguasaan bahasa Arab dan Inggis cenderung ditujukanuntuk kepentingankepentingan praktis. Ketiga, pesantren komprehensif atau kombinasi, pondok pesantren menyelenggarakan pendidikan secara komprehensif karena memadukan sistem pendidikan dan pengajaran gabungan antara tradisional dan modern dengan kurikulum lengkap.

Budaya pondok pesantren paling tidak memiliki lima elemen dasar, yakni pondok, masjid, santri, pengajaran kitab-kitab Islam klasik, kiai (Dhofier, 1982: 44). Menurut Martin Van Bruinessen, salah satu budaya atau tradisi agung (great tradition) di Indonesia adalah tradisi pengajaran agama Islam yang bertujuan untuk mentransmisikan Islam Tradisional sebagaimana yang terdapat dalam kitab-kitab klasik yang ditulis berabad-abad yang lalu (Bruinessen, 1999: 17).

Pondok pesantren tradisional atau modern yang mengajarkan keislaman diselenggarakan dalam bentuk asrama yang merupakan komunitas sendiri di bawah kepemimpinan kiai sebagai manajer puncak, dibantu oleh seorang atau beberapa orang ulama dan para ustadz yang hidup bersama ditengah-tengah para santri dengan masjid atau surau sebagi pusat kegiatan peribadatan keagamaan, gedung sekolah atau ruang-ruang belajar mengajar serta pondok sebagai tempat tinggal santri (Mastuhu, 1994: 6). Budaya organisasi dalam upaya memelihara tata nilai yang menekankan ibadah dan penghormatan kepada guru atau ustadz sebagai jalan memperoleh ilmu pengetahuan agama yang hakiki. Tata nilai yang dianut dan didukung dalam kehidupan pondok pesantren diantaranya adalah konsep Ahlussunnah Wal Jamaah. Istilah ini menunjukkan pada paham yang paling menguasai keseluruhan rasa pengendalian diri (sense of identity) orang-orang pondok pesantren dan selalu menjadi jawaban atas pertanyaan-pertanyaan mengenai golongan atau sistem nilai apa yang dianut (Sudjoko, 199l: 31). Yang kemudian menjadi sebuah perilaku organisasi bagi orang-orang (steakholder) yang 
berada dalam wilayah pondok pesantren yang kemudian menjadi budaya pondok pesantren.

Pola kehidupan interaktif dalam pondok pesantren terjalin diantara kiai, ustadz dan santri. Pola ini mencerminkan pengalaman keagamaan yang dibangun dari nilai-nilai kitab-kitab klasik atau kuning. Komunitas ini lebih lanjut dinamakan lembaga yang memiliki tradisi, kelakuan, norma, atau kaidah hukum. Hal ini berimplikasi pada istilah lembaga yang merupakan kumpulan dari berbagai cara berperilaku yang diakui oleh anggota masyarakat sebagai sarana untuk mengatur hubungan-hubungan sosial. Dengan pola hubungan sosial pondok pesantren seperti ini individu mempunyai kedudukan dan peranan tertentu didalam hubungan sosial sebagai suatu bentuk pergaulan hidup (Abdulsyani, 1994: 76).

\section{Budaya Organisasi dalam Membentuk Karakter Generasi Khaira Ummah di Pondok Pesantren}

Sistem pengelolaan pondok pesantren berbentuk sederhana dengan puncak kepemimpinan di tangan kiai. Namun seringkali kepemimpinannya diwakilkan pada guru senior selaku "lurah pondok". Sering juga pondok pesantren membentuk organisasi pengelola pondok pesantren seperti yayasan, dengan susunan pengurus lengkap dan dengna tugas masing-masing secara jelas, walaupun ketuanya masih disebut "lurah". Tetapi kekuasaan tertinggi tetap berada di tangan kiai. Betapapun demokratisnya kepemimpinan kiai di pondok pesantren, tetap saja masih ada jarak tak terjembatani antara kiai dan keluarganya disatu pihak dan para guru serta santri dipihak lain. Kiai dalam konteks ini bertindak sebagai pemilik tungal (singel owner) (Rahardjo, 1974: 46). Ia dianggap memiliki sesuatu yang tidak dimiliki oleh orang lain disekitarnya, dengan status demikian ia berfungsi sebagai pengasuh dan pembimbing santri dalam banyak hal. Fungsi ini memunculkan peranan kiai peranan kiai sebagai peneliti (researcher), filter dan asimilator terhadap aspek-aspek kebudayaan luar yang masuh kedalam pondok pesantren. Dengan demikian, peranan kiai sebagai culture broke menjadi nyata. 
Aspek-aspek kebudayan yang telah diseleksi oleh kiai akan dikembangkan para santri di masyarakat mereka sendiri (Rahardjo, 1974: 47).

Peran kiai sebagai manajer puncak dalam mengadaptasi nilai-nilai yang baru kedalam tata nilai yang telah dimiliki pondok pesantren relatif dominan, sebagai konsekuensi gaya asketisnya yang kental. Lukens Bull (1997: 12) menjelaskan bahwa, aspek penting lain dari pendidikan pesantren adalah pengembangan watak. Gaya hidup santri adalah asketis. Kondisi kehidupan yang prihatin, makanan yang sederhana, jadwal pelajaran yang ketat dan kepatuhan pada guru yang disebut "kiai". Komponen kedua adalah kiai yang merupakan ilmuan agama yang menjadi guru dan pemimpin karena pengetahuan agama dan kekuatan mistiknya yang tinggi.

Kekuatan asimilasi kiai dengan gaya asketiknya secara tidak sadar telah terlibat dalam proses penyesuaian terus menerus antara nilai yang ada dimasyarakat dan nilai-nilai baru yang menyentuhnya. Sekalipun hanya bersifat reaktif, proses penyesuaian ini setidak-tidaknya menumpulkan ekses-ekses yang dibawa oleh setiap nilai baru (Rahardjo, 1974: 41) dalam budaya organisasi dalam kehidupan pondok pesantren.

Pendidikan di pondok pesantren memberikan kekuatan spiritual kepada mereka pada saat-saat tertentu, terutama dalam menghadapi kemalangan dan kesulitan. Disamping itu pondok pesantren menjadi sumber aspirasi bagi sikap hidup yang diharapkan dapat tumbuh dalam diri pribadi anak-anak mereka, terutama jika sistem pendidikan diluar pondok pesantren tidak dapat memberikan harapan besar bagi terjangkaunya ketentraman dan ketenangan hidup (Rahardjo, 1974: 41).

Nilai-nilai agama adalah tujuan dari sistem pendidikan Islam, yang oleh sebagian besar pondok pesantren direalisasikan melalui jalur penyampaian pengetahuan dan nilai-nilai dasar agama maupun gambaran akhlak dan keistimewaan kultur, guna mencetak para kiai, ulama dan guru (Ziemek, 1986: 157). Tujuan pendidikan pondok pesantren bervariasi, pondok pesantren 
memberikan kontribusi membentuk kepribadian, kemantapan akhlak, dan melengkapi santri dengan ilmu pengetahuan agama Islam dan mencetak generasi khaira ummah. Jika mereka kembali ke masyarakat kemudian menampakkan pribadi yang berakhlak, mengamalkan ototitas ilmu, dan mensosialisasikan tradisi pondok pesantren.

Sistem nilai yang menjadi karakter atau budaya pondok pesantren adalah Ahlussunnah Wal Jamaah (orang-orang yang berpegang teguh pada jejak dan langkah Nabi beserta paa sahabatnya). Konsep tentang Ahlussunnah Wal Jamaah terasa dalam hal fiqih. Para santri di pondok pesantren diwajibkan mengikuti salah satu dari sekurang-kurangnya empat imam mazhab fikif, yaitu Maliki, Syafi'i, Hanafi dan Hambali. Pada umunya pondok pesantren tradisional mengikuti mazhab Syafi'i sebagaimana yang dianut oleh umat Islam di Indonesia.

Pondok pesantren salah satu soko guru pendidikan Islam mampu mengarahkan generasi muda untuk mengerti tentang Islam yang sesungguhnya, sehingga terbentuklah generasi khaira ummah yang menjunjung tinggi keislaman dalam kehidupan berbangsa dan bernegara bawah naungan Negara Kesatuan Republik Indonesia. Pondok pesantren selain menerapkan pengajaran kitab kuning, sistem persekolahan terus harus dikembangkan bahkan pendidikan keterampilan juga diberikan pada para santri. Output ataupun outcome yang dihasilkan diharapkan memiliki kemampuan intelektualitas yang lengkap baik kitab, agama maupun umum ditambah lagi akhlaqul karimah yang menjadi sangat penting untuk menjawab tantangan zaman sekarang sebagaimana yang dicitacitakan pondok pesantren untuk membentuk generasi khaira ummah.

Implementasi generasi khaira ummah di pondok pesantren yang diterapkan dalam sistem nilai dalam budaya pesantren atau budaya organisasi bukan persoalan mudah namun tidak sulit dilakukan. Jika kita melihat lebih dalam surat Ali Imron ayat 110 diatas bahwa umat Islam memiliki potensi untuk tetap menjadi khaira ummah dalam pengertian yang sebenarnya. Selain memiliki kekuatan spiritual berupa nilai-nilai ajaran agama spiritual berupa nilai-nilai ajaran agama 
yang komprehensif dan sejalan dengan fitrah kemanusiaan, umat Islam dibanyak Negara memiliki kekuatan materiil yang berupa kekayaan sumber daya alam dan tentunya kuantitas umat yang mencapai seperempat penduduk dunia (sekitar 1,3 miliar jiwa).

Pondok pesantren dalam tataran spiritual membentuk karakter para santri yang memiliki kesadaran akan pentingnya persatuan umat dengan cara menggembleng pribadi yang berakhlaqul karimah jauh dari sifat-sifat tercela dan membekali dengan berbagai macam intelektualitas dan keterampilan. Sehingga pondok pesantren mendidik semua elemen-elemen baik santri, guru, tata administrasi dan lain sebagaimana untuk menjadi pribadi yang tangguh sebagaimana karakter khaira ummah sesuai dengan sistem nilai yang selama dibentuk.

Pada santri disiapkan dengan berbagai macam kegiatan yang mendukung pembentukan karakter umat yang mampu berbicara disemua bidang baik ilmu agama atau ilmu pengetahuan dan tantangan di era revolusi industri 4.0 serta pada akhirnya mampu mewujudkan perdamaian dunia. Mengingat kondisi teknologi yang selalu berubah, diperlukan kemampuan adaptasi yang tinggi agar santri tidak ketinggalan zaman dan mampu bersaing dan nilai-nilainya sendiri.

Poin penting dalam membentuk generasi khaira ummah di pondok pesantren adalah para santri harus selalu eksis dalam berbagai disiplin ilmu serta memiliki jiwa khairunnas anfa'uhum linnas yaitu para santri yang dapat mmeberikan manfaat pada orang lain dan benar-benar tangguh dapal menghadapi era globalisasi. Menurut Muhammad Najib Suyuthi (2016: 11) seorang pemimpian sekaligus pembina Yayasan Pendidikan Islam Raudlutul Ulum (YPUR) Guyangan Trangkil Pati mengatakan bahwa, ada beberapa poin-poin penting dalam mencetak generasi khaira ummah di pondok pesantren:

a. Ilmu dan amal, karena orang yang memiliki ilmu tetapi memiliki amal akan siasia. 
b. Akhlaqul karimah, karena orang yang mengaku pintar tetapi tak berakhlaq sesungguhnya ia jahil atau bodoh.

c. Ahlussunnah wal jama'ah, karena itu merupakan benteng dari paham-paham menyimpang terutama radikalisme dan terorisme.

d. NKRI, karena itu akan membentuk jiwa kita sebagaimana Negara ini didirikan dengan jiwa raga oleh para pendahulu kita terutama para kyai dan santri.

\section{Simpulan}

Budaya Pondok pesantren dalam tataran spiritual membentuk karakter para santri yang memiliki kesadaran akan pentingnya persatuan umat dengan cara menggembleng pribadi yang berakhlaqul karimah jauh dari sifat-sifat tercela dan membekali dengan berbagai macam intelektualitas dan keterampilan. Sehingga pondok pesantren mendidik semua elemen-elemen baik santri, guru, tata administrasi dan lain sebagaimana untuk menjadi pribadi yang tangguh sebagaimana karakter khaira ummah sesuai dengan sistem nilai yang selama dibentuk.

Pada santri disiapkan dengan berbagai macam kegiatan yang mendukung pembentukan karakter umat yang mampu berbicara disemua bidang baik ilmu agama atau ilmu pengetahuan dan tantangan di era revolusi industri 4.0 serta pada akhirnya mampu mewujudkan perdamaian dunia. Mengingat kondisi teknologi yang selalu berubah, diperlukan kemampuan adaptasi yang tinggi agar santri tidak ketinggalan zaman dan mampu bersaing dan nilai-nilainya sendiri.

\section{DAFTAR PUSTAKA}

Abdulsyani. (1994). Sosiologi: Skematika, Teori dan Terapan. Bumi Aksara.

Al Munawar, S. A. H. (2003). Aktualisasi Nilai-Nilai Qur'ani Dalam Sistem Pendidikan Islam. Ciputat Press.

Bruinessen, M. van. (1999). Kitab Kuning, Pesantren, Dan Tarekat: Tradisi-Tradisi Islam Di Indonesia. Mizan.

Dhofier, Z. (1982). Tradisi Pesantren: Studi Tentang Pandangan Hidup Kiai. LP3ES.

Fatah, A. Y. (2008). Dimensi-Dimensi Pendidikan Islam. UIN Malang Press.

Hidayatullah, M. F. (2010). Guru Sejati: Membangun Insan Berkarakter Kuat Dan 
Cerdas. Yuma Pustaka.

Juwairiyah. (2010). Hadits Tarbawi. Teras.

Kast, F. E., \& Rosenzweig, J. E. (1974). Organization And Management: A Systems Approach. McGraw-Hill.

Kotter, J. P. (2008). Corporate Culture and Performance. Simon and Schuster.

Lukens, R. B. A. (1997). A Peaceful Jihad: Javanese Education And Religion Identity Construction. : Arizona State University.

Majid, N. (1997). Bilik-Bilik Pesantren: Sebuah Potret Perjalanan. Paramadina.

Mastuhu. (1994). Dinamika Sistem Pendidikan Pesantren: Suatu Kajian Tentang Unsur Dan Nilai Sistem Pendidikan Pesantren. INIS.

Munir, A. (2010). Pendidikan Karakter: Membangun Karakter Anak Sejak Dari Rumah. Pustaka Insan Madani.

Rahardjo, D. (1974). Pesantren dan Pembaharuan. LP3ES.

Schein, E. H. (2010). Organizational Culture and Leadership. John Wiley \& Sons.

Sørensen, J. B., \& Sorensen, J. B. (2002). The Strength of Corporate Culture and the Reliability of Firm Performance. Administrative Science Quarterly, 47(1), 70. https://doi.org/10.2307/3094891

Suryono, A. (2001). Budaya Birokrasi Pelayanan Publik. Jurnal Ilmiah Administrasi Negara, 1(2), 49-58.

Suyuthi, M. N. (2016). Generasi Khaia Ummah. Majalah Raudlatina, X.

Tobroni, Pendidikan Karakter Dalam Perspektif Islam, http://tobroni.staff.umm.ac.id/2010/11/24/pendidikan-karakter-dalam-prespektifislam-pendahuluan., diakses pada 17 Juli 2012

Wahjoetomo. (1997). Perguruan Tinggi Pesantren: Pendidikan Alternatif Masa Depan. Gema Insani Press.

Wilkins, A. L., \& Ouchi, W. G. (1983). Efficient Cultures: Exploring the Relationship between Culture and Organizational Performance. Administrative Science Quarterly, 28(3), 468-481.

Ziemek, M. (1986). Pesantren Dalam Perubahan Sosial. Jakarta: Perhimpunan Pengembangan Pesantren dan Masyarakat (P3M). 